\title{
Antifreeze glycopeptide diastereomers
}

\author{
Lilly Nagel ${ }^{1}$, Carsten Budke ${ }^{2}$, Axel Dreyer ${ }^{2}$, Thomas Koop ${ }^{2}$ \\ and Norbert Sewald ${ }^{* 1}$
}

\author{
Full Research Paper \\ Address: \\ ${ }^{1}$ Organic and Bioorganic Chemistry, Department of Chemistry, \\ Bielefeld University, Universitätsstraße 25, 33615 Bielefeld, Germany \\ and ${ }^{2}$ Physical Chemistry, Department of Chemistry, Bielefeld \\ University, Universitätsstraße 25, 33615 Bielefeld, Germany \\ Email: \\ Lilly Nagel - lilly.nagel@uni-bielefeld.de; \\ Carsten Budke - carsten.budke@uni-bielefeld.de; \\ Axel Dreyer - axel.dreyer@uni-bielefeld.de; \\ Thomas Koop - thomas.koop@uni-bielefeld.de; \\ Norbert Sewald* - norbert.sewald@uni-bielefeld.de \\ * Corresponding author \\ Keywords: \\ bioorganic chemistry; circular dichroism; glycopeptides; ice \\ recrystallization; microwave chemistry

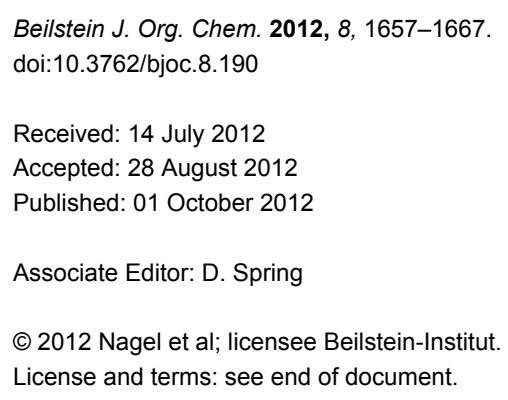

\begin{abstract}
Antifreeze glycopeptides (AFGPs) are a special class of biological antifreeze agents, which possess the property to inhibit ice growth in the body fluids of arctic and antarctic fish and, thus, enable life under these harsh conditions. AFGPs are composed of 4-55 tripeptide units -Ala-Ala-Thr- glycosylated at the threonine side chains. Despite the structural homology among all the fish species, divergence regarding the composition of the amino acids occurs in peptides from natural sources. Although AFGPs were discovered in the early 1960s, the adsorption mechanism of these macromolecules to the surface of the ice crystals has not yet been fully elucidated. Two AFGP diastereomers containing different amino acid configurations were synthesized to study the influence of amino acid stereochemistry on conformation and antifreeze activity. For this purpose, peptides containing monosaccharidesubstituted allo-L- and D-threonine building blocks were assembled by solid-phase peptide synthesis (SPPS). The retro-inverso AFGP analogue contained all amino acids in D-configuration, while the allo-L-diastereomer was composed of L-amino acids, like native AFGPs, with replacement of L-threonine by its allo-L-diastereomer. Both glycopeptides were analyzed regarding their conformational properties, by circular dichroism (CD), and their ability to inhibit ice recrystallization in microphysical experiments.
\end{abstract}

\section{Introduction}

Several fish species living in polar and subpolar oceans have developed a strategy to survive in water at an average temperature of $-1.8{ }^{\circ} \mathrm{C}$. This non-colligative freezing-point depression is based on the prevention of ice growth in physiological solu- tions by biological antifreeze agents AFPs (antifreeze proteins) and AFGPs (antifreeze glycoproteins) [1]. This effect is attained by suppressing the nonequilibrium hysteresis freezing point (HFP) with only a minor change in the equilibrium freezing 
point (EFP) [2-5]. In addition, ice growth is controlled by binding of these macromolecules to the ice surface, thereby inhibiting their growth [1]. AFGPs form a group of biopolymers containing the highly conserved -Ala-Ala-Thr- motif, which is repeated between 4 to 55 times [2,5-8]. Each hydroxy group of the threonine residue is glycosylated with the disaccharide $\beta$-D-galactosyl- $(1 \rightarrow 3)-\alpha-N$-acetyl-D-galactosamine. In spite of the fact that all AFGPs found in arctic and antarctic fish share this structural homology, minor sequence variations occur, such as the replacement of alanine by proline $[9,10]$ or the glycosylated threonine by arginine [11]. Tachibana et al. summarized the essential properties of AFGPs displaying significant antifreeze activity: The disaccharide must be $\alpha$-glycosidically attached to every threonine; the acetylamino moiety has to be present at the $\mathrm{C} 2$ position; the carbohydrates must be galacto-configured; and the $\gamma$-methyl group of the threonine residue is required [12]. AFGPs are classified as small (AFGP6-8) and large AFGPs (AFGP1-5) depending on their electrophoretic properties. Low-molecular-weight AFGPs are supposed to adopt a threefold left-handed helix, which is highly flexible and similar to polyproline helix type II (PPII) [13]. The larger AFGP1-4 are known to form flexible rods with segmental mobility $[14,15]$.

Recent research has been directed toward the assembly of synthetic AFGPs with tailored amino acid composition and glycosylation pattern. The main target is to investigate the influence of sequential mutations on the adsorption of such synthetic AFGP analogues onto ice surfaces, and to corroborate the molecular mechanism of antifreeze activity. Recently, we published the synthesis of monosaccharide-based AFGP analogues containing glycine, proline and serine instead of alanine residues [16]. These analogues exhibit a decreased antifreeze activity compared to glycopeptides with the native sequence (Ala-Ala-Thr). Similar results were obtained by Peltier et al. with synthetic AFGP analogues comprising both the $\mathrm{N}$-acetyl galactosamine as the carbohydrate moiety, and alanine by proline replacements [5]. These peptides exhibit less antifreeze activity than monosaccharide-substituted AFGP analogues without proline residues. Peptoid glycoconjugates with carbohydrate moieties attached by $\mathrm{Cu}^{\mathrm{I}}$ catalyzed azidealkyne cycloaddition (CuAAC) were devoid of antifreeze activity [17]. Another type of modification in the AFGP sequence encompasses $C$-linked analogues. For example, galactosyl substituted peptides with different distances between the carbohydrate and the peptide backbone have been reported. The peptides with the shortest distance between the carbohydrate and the amino acid emerged to be potent inhibitors of recrystallization [18]. Furthermore, triazole-connected glycopeptides with different methylene spacers between the carbohydrate moiety and the triazole residue were generated [19]. In this case, the AFGP analogue comprising the smallest distance did not exhibit activity whereas the peptides with one or two methylene spacers showed moderate activity.

\section{Results and Discussion}

In the frame of our ongoing studies on the structure-activity relationship of AFGPs, we became interested in the question of whether an inversion of the configuration at $\mathrm{C}^{\beta}$ of threonine (replacement of L-threonine by allo-L-threonine) would lead to AFGP analogues with antifreeze activity. In addition, peptides obtained according to the so-called retro-inverso concept have attracted considerable interest in the past [20]. These peptides contain all amino acids in D-configuration (inverso) and the sequence is inverted (retro). Such analogues are supposed to present the amino acid side chains in the same manner as the parent peptides and should, therefore, display analogous activity. Moreover, because of the D-amino acids present, they display, in contrast to their L-configured counterparts, resistance to proteolytic degradation.

Two AFGP mimetics were designed, one comprising exclusively D-configured amino acids and one containing allo-L-Thr. For the glycopeptide synthesis the amino acids Fmoc-D-Thr$\mathrm{OH}$ and Fmoc-allo-L-Thr-OH were glycosylated with $\mathrm{N}$-acetyl galactosamine and incorporated into the peptide by using the stepwise, microwave-enhanced SPPS. Additionally, the corresponding aglycons lacking the carbohydrate moiety were synthesized. The conformation of these synthetic peptides was examined by CD spectroscopic experiments and the antifreeze effect of the glycopeptides was tested in recrystallization assays.

The glycosylation of threonine in $\mathrm{D}$ - and allo-L-configuration with $\mathrm{N}$-acetyl galactosamine relies on an efficient synthetic procedure by Paulsen et al. [21] adapted by us [16,22,23] (Scheme 1). Azidochlorination of a suitably protected L-galactal provides the peracetylated 2-azido-2-desoxygalactopyranosyl chloride serving as a glycosyl donor in a silvermediated Koenigs-Knorr glycosylation of the particular Fmocand $t$-Bu-protected amino acids, i.e., the allo-L-configured (1A) and D-configured (1B) threonine derivatives. Both glycosylated amino acids (2) were obtained in good yields and very good anomeric ratios $(\mathbf{2 A}: \alpha / \beta$ 9:1; 2B: $\alpha / \beta$ 20:1). The azido group was easily reduced and concomitantly acetylated to establish the $N$-acetyl group in the $C 2$ position with thioacetic acid in the presence of pyridine $[24,25]$. The anomers could be easily separated at this stage by column chromatography. In the subsequent step the pure $\alpha$-product $\mathbf{3 A} / \mathbf{3 B}$ was subjected to tert-butyl ester cleavage with TFA.

Peptide synthesis was accomplished under microwave heating in a semi-automated fashion, as previously published by us 


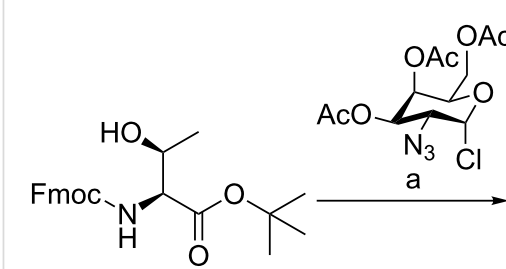

$1 \mathrm{~A}$

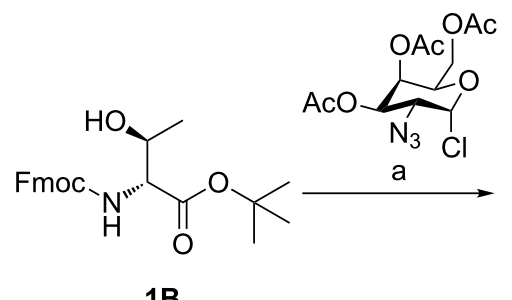

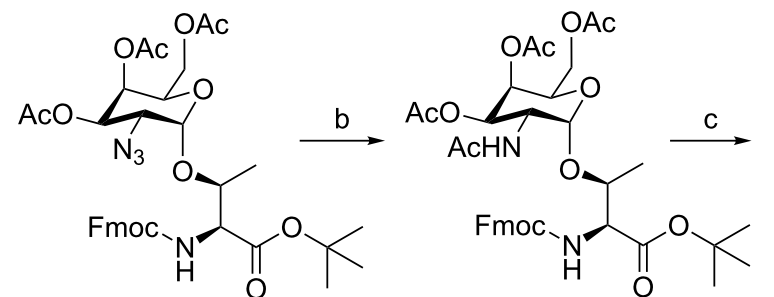

3A

2A<smiles></smiles>

4A<smiles>CC(=O)NC(C(=O)OC(C)(C)C)C(C)OC1OC(OC(C)=O)C(OC(C)=O)C(OC(C)=O)C1N</smiles>

2B

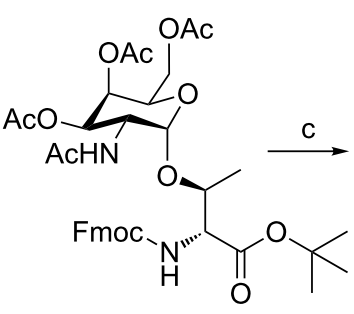

3B<smiles></smiles>

4B

Scheme 1: Synthesis of the monosaccharide-substituted threonine building block $(\mathbf{A}=$ allo-L-threonine; $\mathbf{B}=\mathrm{D}$-threonine $)$. (a) $\mathrm{Ag}_{2} \mathrm{CO}_{3}, \mathrm{AgClO}_{4}$, $\mathrm{CH}_{2} \mathrm{Cl}_{2} /$ toluene (1:1), rt, $40 \mathrm{~h}, 68 \%(\mathbf{A})$ and $67 \%(B)$; (b) AcSH/pyridine (2:1), toluene, $50{ }^{\circ} \mathrm{C}, 30 \mathrm{~min}, 56 \%\left(\right.$ A) and $42 \%$ (B); (c) TFA/ $\mathrm{H}_{2} \mathrm{O}(95: 5)$, $90 \mathrm{~min}, 96 \%$ (A) and $90 \%(\mathbf{B})$.

[16,23], by employing 2-chlorotrityl resin loaded with Fmoc-LAla-OH or Fmoc-D-Ala-OH. After assembly of the glycopeptides the acetate protecting groups of the carbohydrates were cleaved with $5 \%$ hydrazine in DMF followed by the cleavage of the peptide from the resin with $2 \%$ aqueous TFA. Subsequently, the peptides were precipitated with cold diethyl ether and the solid residues were purified by preparative HPLC. In the case of the aglycons ( $\mathbf{6}$ and $\mathbf{8}$ ) the remaining solids were treated with a high concentration of TFA to cleave the $t$-Bu-protecting groups at the hydroxy group in the side chain of every threonine. These peptides were then purified by HPLC.

The conformations of the allo-Thr AFGP analogue 5, the retroinverso AFGP analogue 7, and their corresponding aglycons 6 and $\mathbf{8}$ (Scheme 2) were analyzed be CD spectroscopy in water at room temperature and additionally at temperatures between

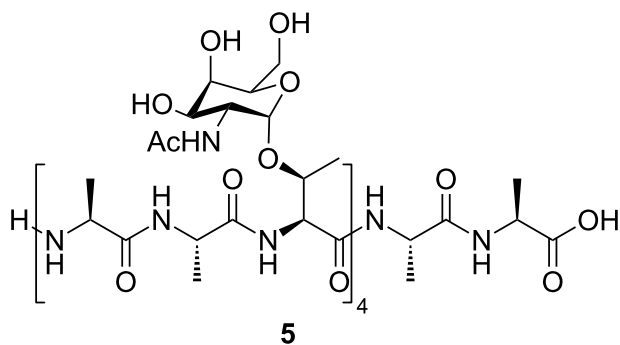<smiles>CC(C)N[C@@H](C)C(=O)N[C@@H](C)C(=O)N[C@@H](C)C(=O)N[C@@H](C)C(=O)NC(C)C(=O)O</smiles>

5

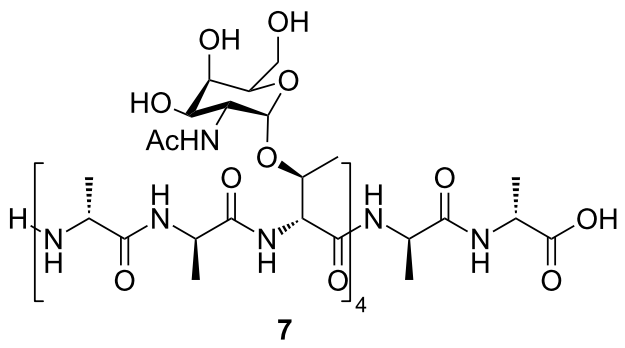<smiles>CN[C@@H](C)C(=O)N[C@@H](C)C(=O)N[C@@H](C)C(=O)N[C@@H](C)C(=O)N[C@@H](C)C(=O)NC(C)C(=O)O</smiles>

Scheme 2: Structures of monosaccharide-substituted AFGP analogues containing allo-L-threonine and L-alanine 5, the corresponding aglycon $\mathbf{6}$, the L-glycopeptide comprising D-threonine and D-alanine 7, and the aglycon 8. 
-10 and $+80{ }^{\circ} \mathrm{C}$. The allo-L-threonine containing glycopeptide 5 shows a CD signature typical of a PPII-like conformation with a negative band at $\lambda \approx 197 \mathrm{~nm}$ and a weak positive CD effect at about $220 \mathrm{~nm}$ (Figure 1), as already observed for other synthetic AFGP analogues [16,23]. However, the CD intensity is significantly lower compared to the previously published correlate 9 with the native sequence [16]. The $(2 S, 3 S)$-configuration of the glycosylated allo-L-threonine obviously leads to changes of the conformation compared to glycopeptide 9 containing $(2 S, 3 R)$-threonine. The temperature-dependent $\mathrm{CD}$ experiments of peptide 5 show an isodichroic point at $\lambda \approx 207 \mathrm{~nm}$ indicating a conformational transition (Figure 2a), presumably between the polyproline II (PPII) helix and the random coil. The difference spectrum generated by subtracting the spectrum at $-10{ }^{\circ} \mathrm{C}$ from the one recorded at $+80^{\circ} \mathrm{C}$ indicates a slight increase in $\beta$-structures (e.g., $\beta$-turns, Figure 2b) $[26,27]$. Glycopeptide 5 presumably undergoes a local transition from a conformational mixture of PPII and random coil at low temperature to a combination of $\beta$-structures and random coil at higher temperature [28$30]$. In contrast, the corresponding aglycon 6 shows a negative CD effect at $\lambda \approx 195 \mathrm{~nm}$ comparable to 5 but no positive band (Figure 1). The temperature-dependent $\mathrm{CD}$ experiments reveal an isodichroic point at $\lambda \approx 209 \mathrm{~nm}$ indicating a conformational equilibrium (Figure $3 \mathrm{a}$ ). The difference spectrum reveals a typical $\beta$-sheet- or $\beta$-strand-like structure (Figure $3 b$ ). The propensity to adopt a PPII helical structure is reduced in the aglycon 6 compared to the glycopeptide 5 . The high $\beta$-sheetand $\beta$-strand-like character is already visible in the CD curve recorded at $50{ }^{\circ} \mathrm{C}$ (Figure 3a). Interestingly, unlike the aglycon 10, which contains L-threonine, the aglycon 6 containing alloL-threonine does not as readily adopt a $\beta$-sheet-like structure at room temperature (Figure 1) [16]. The difference in configuration at $C^{\beta}$ of the threonine residue seems to reduce the propen-

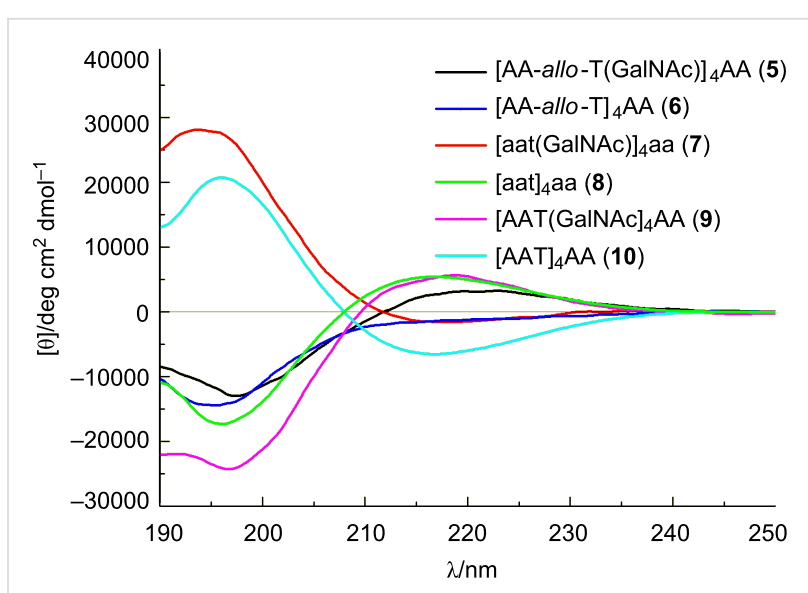

Figure 1: CD spectra of the monosaccharide-substituted AFGP analogues ( 5 and 7 ) and their corresponding aglycons ( 6 and 8 ) measured at a concentration of $0.2 \mathrm{mg} \mathrm{mL}^{-1}$ in water at $20^{\circ} \mathrm{C}$. For comparison, the spectra of monosaccharide-substituted glycopeptide with naturally occurring sequence $\mathbf{9}$ and its correlate aglycon $\mathbf{1 0}$ are shown [16]. Capital letters symbolize L-amino acids ( $\mathrm{A}=\mathrm{L}-\mathrm{Ala}, \mathrm{T}=$ $\mathrm{L}$-Thr), lowercase letters D-amino acids ( $\mathrm{a}=\mathrm{D}$-Ala, $\mathrm{t}=\mathrm{D}$-Thr).

sity for $\beta$-strand formation. In the $\varphi / \psi$-energy map the conformers PPII and $\beta$-strand are very close, and the energy barrier is quite low, facilitating the transition between the conformers $[31,32]$.

For the retro-inverso peptides $\mathbf{7}$ and $\mathbf{8}$, containing exclusively D-configured amino acids, contrasting results were observed. The CD spectrum of AFGP analogue 7 is nearly a mirror image to the CD spectrum obtained for glycopeptide 9 with almost equivalent ellipticities but, as expected for a D-configured peptide, opposite signs (Figure 1). Small deviations in the CD spectrum of 7 can be attributed to the influence of the carbohydrate moieties, which are D-configured in both glycopeptides. (a)

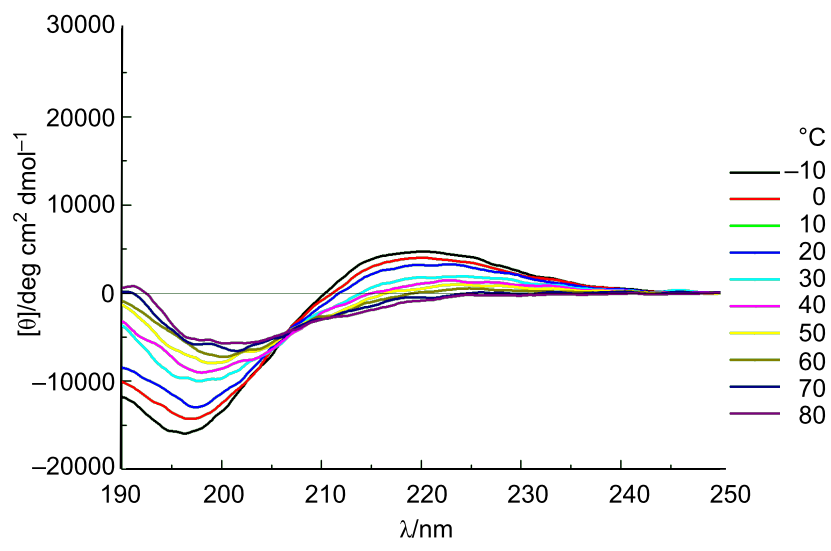

(b)

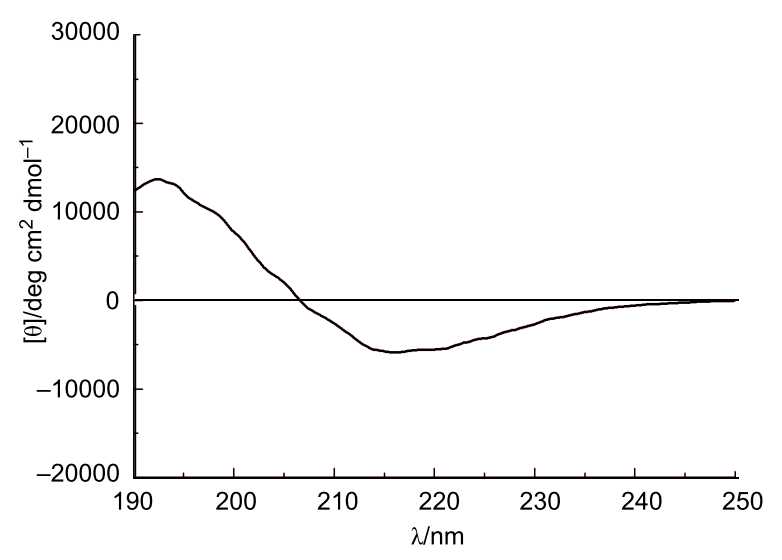

Figure 2: (a) Temperature dependent CD spectra of the glycosylated allo-L-Thr containing peptide 5 from -10 to $80^{\circ} \mathrm{C}$ in water, revealing an isodichroic point at $207 \mathrm{~nm}$; and (b) the difference spectra between +80 and $-10^{\circ} \mathrm{C}$, indicating the contribution of a $\beta$-like structure. 
(a)

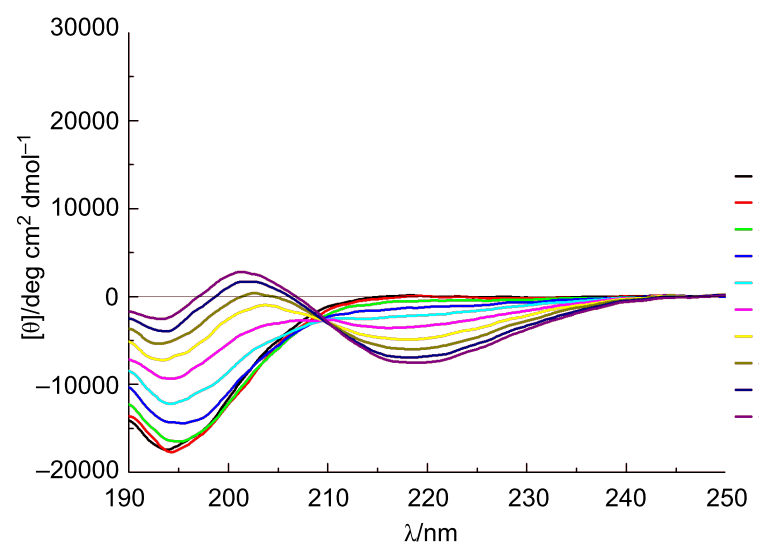

(b)

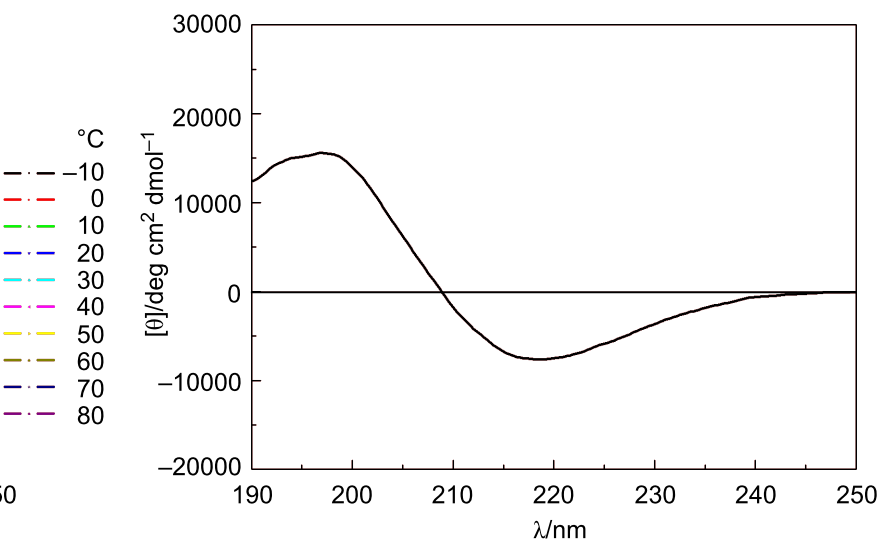

Figure 3: (a) Temperature-dependent CD spectra of the aglycon comprising allo-L-Thr 6 from -10 to $80{ }^{\circ} \mathrm{C}$ in water, revealing an isodichroic point at $209 \mathrm{~nm}$; and (b) the difference spectra between +80 and $-10^{\circ} \mathrm{C}$ indicating the contribution of a $\beta$-like structure.

The absolute intensity of the band at $194 \mathrm{~nm}$ of the retroinverso peptide 7 is slightly increased compared to that of $\mathbf{9}$, while it is less intense for the band of 7 at $217 \mathrm{~nm}$. This may be attributed to decreased PPII character of 7 . Temperature-dependent CD spectra reveal an isodichroic point at $\lambda \approx 203 \mathrm{~nm}$ indicating a conformational transition (Figure $4 \mathrm{a}$ ). The difference spectrum generated by subtracting the CD spectra of -10 from $+80{ }^{\circ} \mathrm{C}$ exhibits a curve indicating a transition from PPII/ random coil structures at lower temperatures to an increasing proportion of $\beta$-turn structures (Figure 4b). Aglycon 8, the enantiomer of the all-L-peptide 10, exhibits the mirror image CD spectrum (Figure 1) [33]. Furthermore, the peptide conformation is temperature-independent as judged by the absence of significant changes of the CD spectrum with increasing temperature. The aglycon $\mathbf{8}$ adopts only $\beta$-sheet structure as shown for the aglycon $\mathbf{1 0}$ containing exclusively L-amino acids [16].

The allo-L-threonine analogue 5 and the retro-inverso analogue 7 were tested in this study in an ice-recrystallization-inhibition assay [34-37]. In the absence of any active additives a polycrystalline ice sample undergoes Ostwald ripening at constant temperatures driven by the reduction of the total ice/solution interface energy. During this recrystallization process the amount of ice stays constant while the number of crystals decreases, and hence, the average size increases (Figure 5a). (a)

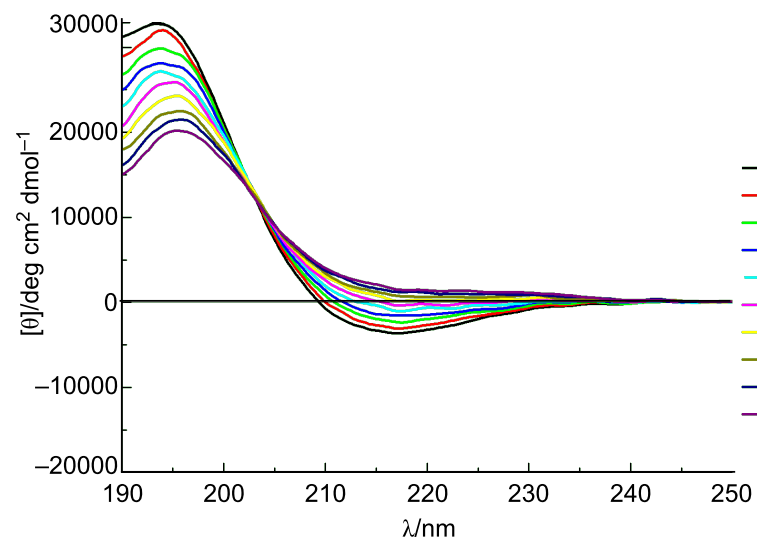

(b)

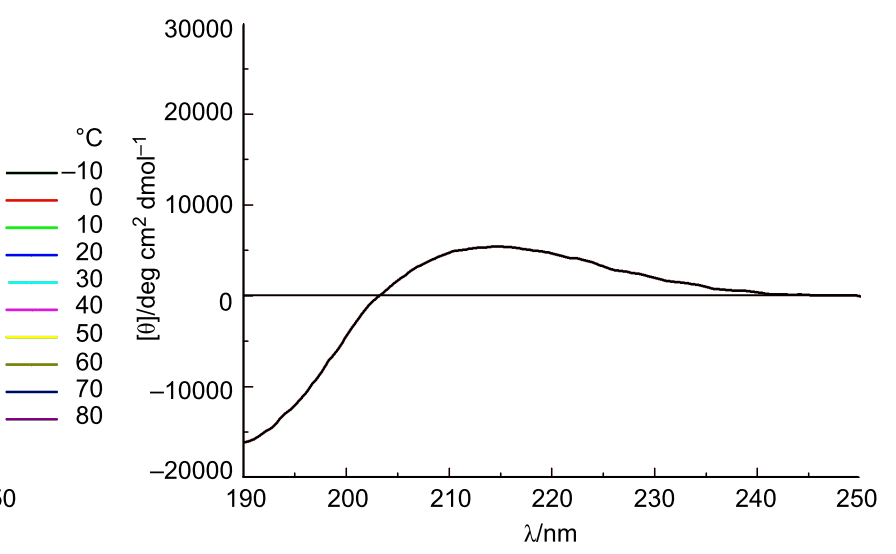

Figure 4: (a) Temperature-dependent $C D$ spectra of the glycosylated D-Thr and D-Ala containing peptide 7 from -10 to $80{ }^{\circ} \mathrm{C}$ in water, revealing an isodichroic point at $203 \mathrm{~nm}$; and (b) the difference spectra between +80 and $-10^{\circ} \mathrm{C}$. 
The rate of this process is controlled predominantly by the diffusion of water molecules between the adjacent ice crystals. In the presence of ice-binding antifreeze agents, however, the limiting factor becomes the liquid-to-ice transfer. In the case of sufficiently large concentrations of antifreeze agents the recrystallization is retarded or even entirely inhibited. The monoglycosylated peptide 9 ([AAT(GalNAc) $\left.]_{4} \mathrm{AA}\right)$, comprising L-amino acids, reduced the recrystallization rate already at concentrations of about $c_{\mathrm{i}} \approx 20 \mu \mathrm{g} \mathrm{mL}^{-1}(0.01 \mathrm{mM})$ [37]. Figure $5 \mathrm{~d}$ shows the result of an experiment at $c \approx 200 \mu \mathrm{g} \mathrm{mL}^{-1}$ of peptide 9 , at which the ripening is totally inhibited after a few minutes. In contrast, the peptides $\mathbf{5}$ and $\mathbf{7}$ do not inhibit ice recrystallization significantly in the investigated concentration range from 100 up to $1000 \mu \mathrm{g} \mathrm{mL}^{-1}(0.5 \mathrm{mM}$, Figure $5 \mathrm{~b}, \mathrm{c})$. After 120 min the crystal number had decreased and the average size had increased by Ostwald ripening similar to the control solution without any peptides.

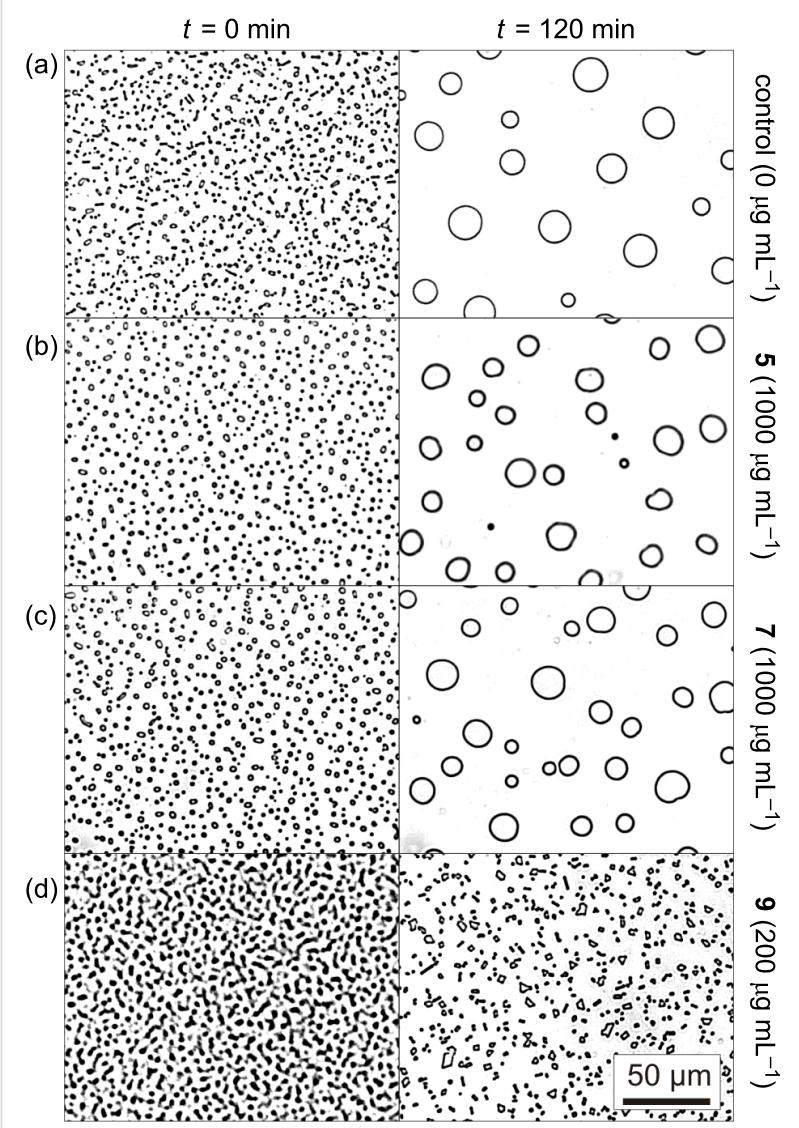

Figure 5: Optical microphotographs taken after 0 and 120 min during the recrystallization process of polycrystalline ice samples at $-8{ }^{\circ} \mathrm{C}$ formed in aqueous 45 wt \% sucrose solutions. (a) Negative control solution without peptides. (b) Peptide 5 (c $\left.1000 \mu \mathrm{gL}^{-1}\right)$. (c) Peptide 7 (c $1000 \mu \mathrm{g} \mathrm{mL}^{-1}$ ). (d) Positive control solution containing $200 \mu \mathrm{g} \mathrm{mL}^{-1}$ of the ice recrystallization inhibiting peptide 9 ([AAT(GalNAc) $]_{4} A A$ ). The pictures were contrast-enhanced for better visibility.
The propensity of an AFGP analogue to adopt PPII-helical structure is obviously not the only precondition to qualify it as an antifreeze agent [38]. The GalNAc-allo-Thr containing peptide 5 forms a PPII helix, albeit with decreased propensity. However, $\mathbf{5}$ is devoid of antifreeze activity, as it does not inhibit ice recrystallization. The retro-inverso AFGP analogue 7 adopts a PPII helix with opposite helicity. The D-configured peptide backbone might, therefore, qualify for interaction with the achiral ice surface. However, the combination of a D-configured PPII helical peptide with the native D-GalNAc residues abolishes antifreeze activity. Although the peptide backbone of 7 is the mirror image of the native parent compound $\mathbf{9}$, which adopts a right-handed helix, no activity was obtained for the retro-inverso analogue 7 . The different behavior can be explained only by a change in the conformational presentation of the GalNAc residue and altered interaction pattern (e.g., by hydrogen bonds) between peptide and carbohydrate. According to the literature, model studies have provided indications that a carbohydrate such as $\mathrm{N}$-acetyl-D-galactosamine influences the conformation by interactions such as hydrogen bonding and the presence of water pockets/bridges between the monosaccharide and the peptide backbone $[39,40]$. Hence, both configurational and conformational elements of the glycopeptides are essential for antifreeze activity. The $(2 S, 3 S)$-configured allo-L-threonine may direct the carbohydrate moiety into an unfavorable position for adsorption to the ice surface; a similar situation applies to the retro-inverso peptide 7. Moreover, these conformational changes may possibly also alter the water hydration shell around the peptide, which has been suggested to be essential for the antifreeze activity of AFGPs and AFGP analogues $[41,42]$.

\section{Conclusion}

A GalNAc-substituted AFGP analogue [AA-allo$\mathrm{T}(\mathrm{GalNAc})]_{4} \mathrm{AA}(5)$ and a retro-inverso AFGP analogue [aat(GalNAc) $]_{4}$ aa (7) with GalNAc-D-Thr and D-Ala building blocks were synthesized. The conformations of these glycopeptides and their corresponding aglycons were investigated by CD spectroscopy. According to these data, both peptides adopt polyproline II helical conformations, albeit with reduced propensity (5) or opposite helicity (7).

The structure of the glycopeptides was correlated with their ability to inhibit ice growth in microphysical recrystallization assays. Both AFGP analogues $\mathbf{5}$ and $\mathbf{7}$ did not show antifreeze activity. Hence, the altered configuration at $\mathrm{Thr} \mathrm{C}^{\beta}$ of $\mathbf{5}$ or at Thr $\mathrm{C}^{\alpha} / \mathrm{C}^{\beta}$ of 7 may position the carbohydrate residue differently with implications on the formation of hydrogen bonds and the presence of water pockets/bridges between the monosaccharide and the peptide backbone as well as on the hydration shell around the peptide. 


\section{Experimental}

All chemicals were acquired from Sigma Aldrich (Hamburg, Germany), Acros (Geel, Belgium), Alfa Aesar (Ward Hill, USA) and VWR (Darmstadt, Germany) and were employed without additional purification. Moisture- and air-sensitive reaction steps were conducted in flame-dried glassware under an argon atmosphere. Dichloromethane and toluene were freshly distilled from $\mathrm{CaH}_{2}$ and $\mathrm{Na}$, respectively. Dimethylformamide was distilled from ninhydrin. 2-Chlorotrityl resin ChemMatrix resin $(0.6 \mathrm{mmol} / \mathrm{g})$, coupling reagents and all amino acids were purchased from Iris Biotech (Marktredwitz, Germany), Orpegen (Heidelberg, Germany) and Molekula (Gillingham, Dorset, UK). Peptide synthesis was executed on a Liberty Automated Microwave Peptide Synthesizer (CEM, Kamp-Lintfort, Germany). For preparative RP-HPLC a Thermo Separation Products system equipped with a UV-1000 detector, a P-4000 pump, a Vydac high-performance guard column (C18) and a Phenomenex Jupiter $10 \mu$ Proteo $90 \AA$ column $(\mathrm{C} 12 ; 250 \times$ $21.20 \mathrm{~mm}$ ) or a Hitachi Merck LaChrom system equipped with a UV-vis L-7420 detector and a L-7150 pump equipped with a Vydac high-performance guard column (C18) and a Phenomenex Jupiter $10 \mu 300 \AA$ column $(\mathrm{C} 18 ; 250 \times 21.20$ $\mathrm{mm}$ ) was used. A flow rate of $7.5 \mathrm{~mL} \mathrm{~min}^{-1}$ using eluent $\mathrm{A}$ : $\mathrm{H}_{2} \mathrm{O} / \mathrm{CH}_{3} \mathrm{CN} / \mathrm{TFA}$ (98:1.95:0.05) and eluent B: $\mathrm{CH}_{3} \mathrm{CN} / \mathrm{H}_{2} \mathrm{O} /$ TFA (95:4.9:0.1) was employed. The gradient was executed within $30 \mathrm{~min}$ from 100 to $90 \%$ eluent B ending after $60 \mathrm{~min}$ at $50 \%$ eluent B. MALDI-TOF mass spectra were measured on a Voyager DE Instrument (PE Biosystems, Weiterstadt, Germany) mounted with a $1.2 \mathrm{~m}$ flight tube. 2,5-Dihydroxybenzoic acid was used as the matrix. Depending on the mass range the ions were accelerated at 15 to $25 \mathrm{kV}$ with the option of detecting positive or negative ions. The instrument default calibration was used for calibrating the mass axis. ESI experiments were performed on a Fourier Transform Ion Cyclotron Resonance (FT-ICR) mass spectrometer APEX III (Bruker Daltonik, Bremen, Germany) equipped with a 7.0 T, $160 \mathrm{~mm}$ bore superconducting magnet (Bruker Analytik GmbH - Magnetics, Karlsruhe, Germany), infinity cell, and interfaced to an external (nano)ESI or MALDI ion source. Scan accumulation and Fourier transformation were done with XMASS NT (7.08) on a PC workstation; for further data processing DataAnalysis ${ }^{\mathrm{TM}} 3.4$ was used. Optical rotation was measured on a DIP-360 digital polarimeter (Jasco, Groß-Umstadt, Germany) at $20-23{ }^{\circ} \mathrm{C}$. NMR spectra were recorded on a DRX 500 and an Avance 600 spectrometer (Bruker Biospin, Rheinstetten, Germany). CD spectra were obtained on a J-810 spectrometer equipped with a CDF-4265 Peltier unit for temperature control (Jasco, GroßUmstadt, Germany). The spectra were recorded in the range of $190-250 \mathrm{~nm}$ at a scanning rate of $50 \mathrm{~nm} \mathrm{~min}{ }^{-1}$ with three accumulations, a data pitch of $0.2 \mathrm{~nm}$, a spectral band width of $1 \mathrm{~nm}$ and a response time of $1 \mathrm{~s}$. The peptide solutions had a concen- tration of $0.2 \mathrm{mg} \mathrm{mL}^{-1}$ and were measured in a $0.1 \mathrm{~cm}$ quartz cell. Molar ellipticity per amino acid residue $[\theta]_{\mathrm{mr}}$ was calculated as follows: $[\theta]_{\mathrm{mr}}=\theta /(10 \bullet N \bullet C \bullet l) . \theta$ represents the ellipticity in millidegrees, $N$ the number of amino acid residues, $c$ the molar concentration in moles per liter, and $l$ the cell path length in centimeters. Temperature dependent spectra were measured in a range of -10 to $80^{\circ} \mathrm{C}$ by increasing the temperature in intervals of $5{ }^{\circ} \mathrm{C}$. The temperature slope was $1{ }^{\circ} \mathrm{C} \mathrm{min}-1$ with an equilibration time of $5 \mathrm{~min}$. The $\mathrm{CD}$ spectra were smoothed by a Savitzky-Golay method.

\section{General synthetic procedure for the glycosyl- ation step (GP1)}

The glycosyl acceptors Fmoc-L-allo-Thr-Ot-Bu (1A) and Fmoc-D-Thr-Ot-Bu (1B, 1.0 equiv), respectively, and $\mathrm{Ag}_{2} \mathrm{CO}_{3}$ (1.5 equiv) were suspended with freshly activated, powdered $4 \AA$ molecular sieves in abs toluene $(30-40 \mathrm{~mL})$ and methylene chloride (30-40 mL) at $-20{ }^{\circ} \mathrm{C}$ and stirred for $30 \mathrm{~min}$. Then, the silver salt promoter $\mathrm{AgClO}_{4}$ ( 0.25 equiv) was added at room temperature and stirring was continued for $30 \mathrm{~min}$. Subsequently, the 2-azido-2-deoxy-3,4,6-tri- $O$-acetyl- $\alpha$-D-galactopyranosyl chloride (1.5 equiv) was added dissolved in abs toluene (30-40 mL) and methylene chloride $(30-40 \mathrm{~mL})$, and the solution was stirred in the dark under argon atmosphere at room temperature overnight. The mixture was diluted with methylene chloride (140-200 mL), filtered through Celite and washed with water $(70-100 \mathrm{~mL})$ and aqueous saturated $\mathrm{NaHCO}_{3}$ solution $(50-70 \mathrm{~mL})$. The organic layer was dried over $\mathrm{Na}_{2} \mathrm{SO}_{4}$, and the solvent was removed in vacuo. The crude product was purified by column chromatography (PE/EtOAc; 2:1) yielding a white solid.

$\mathrm{N}$-[(9H-Fluoren-9-yl)methoxycarbonyl]-3-O-(2-azido2-deoxy-3,4,6-tri-O-acetyl- $\alpha$-D-galactopyranosyl)-L-allothreonine tert-butyl ester (2A): Yield from $\mathbf{1 A}(3.00 \mathrm{~g}, 8.6$ mmol) using GP1: $4.17 \mathrm{~g}(5.9 \mathrm{mmol}, 68 \%)$ in $\alpha / \beta$ ratio 9:1; $[\alpha]_{\mathrm{D}}{ }^{20}+50.9\left(c 0.45, \mathrm{CHCl}_{3}\right) ;{ }^{1} \mathrm{H} \mathrm{NMR}\left(500 \mathrm{MHz}, \mathrm{CDCl}_{3}\right) \delta$ 1.42 (d, $J=6.6 \mathrm{~Hz}, 3 \mathrm{H}, \mathrm{H} \gamma-\mathrm{Thr}), 1.54$ (s, 9H, $\left.\mathrm{CH}_{3}-t-\mathrm{Bu}\right), 2.02$ (s, 3H, $\mathrm{CH}_{3} \mathrm{CO}$ ), 2.07 (s, 3H, $\left.\mathrm{CH}_{3} \mathrm{CO}\right), 2.18$ (s, 3H, $\mathrm{CH}_{3} \mathrm{CO}$ ), $3.61(\mathrm{dd}, J=11.3,3.4 \mathrm{~Hz}, 1 \mathrm{H}, \mathrm{H} 2-\mathrm{Gal}), 4.12-4.15$ (m, $3 \mathrm{H}$, H6-Gal, H $\beta$-Thr), 4.25 (m, 1H, H5-Gal), 4.41-4.45 (m, 3H, $\mathrm{H} \alpha$-Thr, $\mathrm{CH}_{2}$-Fmoc), 5.01 (d, $\left.J=3.4 \mathrm{~Hz}, 1 \mathrm{H}, \mathrm{H} 1-\mathrm{Gal}\right), 5.35$ (dd, $J=3.1,11.3 \mathrm{~Hz}, 1 \mathrm{H}, \mathrm{H} 3-\mathrm{Gal}), 5.48(\mathrm{~m}, J=3.0 \mathrm{~Hz}, 1 \mathrm{H}$, H4-Gal), 5.72 (d, $J=6.3 \mathrm{~Hz}, 1 \mathrm{H}, \mathrm{CH}-\mathrm{Fmoc}$ ), 6.06 (d, $J=8.1$ $\mathrm{Hz}, 1 \mathrm{H}, \mathrm{NH}-\mathrm{Thr}), 7.31-7.45(\mathrm{~m}, 4 \mathrm{H}$, aryl-H), 7.61-7.67 (m, $2 \mathrm{H}$, aryl-H), 7.76-7.81 (m, 2H, aryl-H); ${ }^{13} \mathrm{C} \mathrm{NMR} \mathrm{(125.8} \mathrm{MHz,}$ $\left.\mathrm{CDCl}_{3}\right) \delta 14.2(\mathrm{H} \gamma-\mathrm{Thr}), 20.7\left(\mathrm{CH}_{3} \mathrm{CO}\right), 21.1\left(2 \times \mathrm{CH}_{3} \mathrm{CO}\right)$, $28.1\left(\mathrm{CH}_{3}-t-\mathrm{Bu}\right), 47.2$ (CH-Fmoc), 59.1 (C2-Gal), $59.8(\mathrm{C} \alpha-$ Thr), 61.9 (C5-Gal), 67.3 (C4-Gal), 67.8 ( $\mathrm{CH}_{2}$-Fmoc, C6-Gal), 69.8 (C3-Gal), 78.4 (C $\beta-T h r), 83.3$ (C-t-Bu), 98.4 (C1-Gal), $120.0(2 \times), 125.1(2 \times), 127.1(2 \times), 127.7(2 \times), 141.3(2 \times)$, 
143.8 (2×) (aryl), 156.7 (CO-Fmoc), 168.1, 169.6, 170.0, 170.5 (CO); MS (ESI) $m / z:[\mathrm{M}+\mathrm{Na}]^{+} 733.3$.

$\mathrm{N}$-[(9H-Fluoren-9-yl)methoxycarbonyl]-3-O-(2-azido2-deoxy-3,4,6-tri- $O$-acetyl- $\alpha$-D-galactopyranosyl)-D-threonine tert-butyl ester (2B): Yield from 1B (5.00 g, $12.6 \mathrm{mmol})$ using GP1: $5.99 \mathrm{~g}(8.4 \mathrm{mmol}, 67 \%)$ in $\alpha / \beta$ ratio $20: 1 ;[\alpha]_{\mathrm{D}}{ }^{20}$ $+73.7\left(\right.$ c 0.5, $\left.\mathrm{CHCl}_{3}\right) ;{ }^{1} \mathrm{H} \mathrm{NMR}\left(500 \mathrm{MHz}, \mathrm{CDCl}_{3}\right): \delta 1.29(\mathrm{~d}, J$ $=6.2 \mathrm{~Hz}, 3 \mathrm{H}, \mathrm{H} \gamma-\mathrm{Thr}), 1.51\left(\mathrm{~s}, 9 \mathrm{H}, \mathrm{CH}_{3}-t-\mathrm{Bu}\right), 2.03(\mathrm{~s}, 3 \mathrm{H}$, $\mathrm{CH}_{3} \mathrm{CO}$ ), 2.08 (s, 3H, $\left.\mathrm{CH}_{3} \mathrm{CO}\right), 2.14$ (s, 3H, $\left.\mathrm{CH}_{3} \mathrm{CO}\right), 3.61$ (dd, $J=11.2,3.5 \mathrm{~Hz}, 1 \mathrm{H}, \mathrm{H} 2-\mathrm{Gal}), 4.03$ (m, 1H, H5-Gal), 4.09-4.15 (m, 2H, H6-Gal), 4.21-4.27 (m, 2H, $\mathrm{CH}_{2}$-Fmoc, CH-Fmoc),

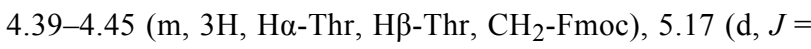
$3.6 \mathrm{~Hz}, 1 \mathrm{H}, \mathrm{H} 1-\mathrm{Gal}), 5.31(\mathrm{~m}, 1 \mathrm{H}, \mathrm{H} 3-\mathrm{Gal}), 5.42(\mathrm{~m}, 1 \mathrm{H}$, H4-Gal), 5.54 (d, $J=9.5 \mathrm{~Hz}, 1 \mathrm{H}, \mathrm{NH}-\mathrm{Thr}), 7.29-7.42$ (m, 4H, aryl-H), 7.60-7.63 (m, 2H, aryl-H), 7.75-7.78 (m, 2H, aryl-H); ${ }^{13} \mathrm{C}$ NMR $\left(125.8 \mathrm{MHz}, \mathrm{CDCl}_{3}\right) \delta 15.0(\mathrm{C} \gamma-\mathrm{Thr}), 20.8(2 \times$ $\mathrm{CH}_{3} \mathrm{CO}$ ), 21.2 ( $\left.\mathrm{CH}_{3} \mathrm{CO}\right), 28.1\left(\mathrm{CH}_{3}-t-\mathrm{Bu}\right), 47.3$ (CH-Fmoc), 57.4 (C2-Gal), 59.2 (C $\alpha$-Thr), 60.5 (C5-Gal), 61.7 (C6-Gal), 67.4 ( $\mathrm{CH}_{2}$-Fmoc), 67.5 (C3-Gal), 67.7 (C4-Gal), 72.6 (C $\left.\beta-\mathrm{Thr}\right)$, 83.3 (C-t-Bu), 95.0 (C1-Gal), $120.0(2 \times), 125.3(2 \times), 127.2$ $(2 \times), 127.9(2 \times), 141.5(2 \times), 143.9,144.0$ (aryl), 156.7 (COFmoc), 169.3, 169.9, 170.2, 170.5 (CO); MS (ESI) $m / z$ : [M + $\mathrm{Na}]^{+} 733.2$.

\section{General synthetic procedure for the simulta- neous reduction and $\mathrm{N}$-acetylation step (GP2)}

Fmoc-L-allo-Thr( $\left.\alpha / \beta-\mathrm{Ac}_{3} \mathrm{GalN}_{3}\right)-\mathrm{O} t$-Bu (2A) or Fmoc-D$\operatorname{Thr}\left(\alpha / \beta-\mathrm{Ac}_{3} \mathrm{GalN}_{3}\right)-\mathrm{O} t$-Bu (2B) was dispensed in a mixture of thioacetic acid and pyridine $(2: 1)$ and stirred at $50{ }^{\circ} \mathrm{C}$ for $30 \mathrm{~min}$. The solvents were distilled off azeotropically three times with toluene. The residue was purified by flash chromatography (PE/EtOAc; $1: 1)$ to give diastereochemically pure $\alpha$-configured product.

$\mathrm{N}$-[(9H-Fluoren-9-yl)methoxycarbonyl]-3-O-(2-acetamido2-deoxy-3,4,6-tri- $O$-acetyl- $\alpha$-D-galactopyranosyl)-L-allothreonine tert-butyl ester (3A): Yield from 2A (4.17 g, 5.9 mmol) using GP2: $2.40 \mathrm{~g}(3.3 \mathrm{~mol}, 56 \%) ;[\alpha]_{\mathrm{D}}{ }^{20}+72.2$ (c 0.69 , $\left.\mathrm{CHCl}_{3}\right) ;{ }^{1} \mathrm{H}$ NMR $\left(500 \mathrm{MHz}, \mathrm{CDCl}_{3}\right) \delta 1.30(\mathrm{~d}, J=7.2 \mathrm{~Hz}, 3 \mathrm{H}$, $\mathrm{H} \gamma$-Thr), 1.54 (s, 9H, $\mathrm{CH}_{3}-t-\mathrm{Bu}$ ), 1.96 (s, 3H, $\mathrm{CH}_{3} \mathrm{CO}$ ), 2.02 (s, $3 \mathrm{H}, \mathrm{CH}_{3} \mathrm{CO}$ ), 2.07 (s, 3H, $\mathrm{CH}_{3} \mathrm{CO}_{\mathrm{NAc}}$ ), 2.18 (s, 3H, $\mathrm{CH}_{3} \mathrm{CO}$ ), 4.08 (m, $J=6.8 \mathrm{~Hz}, 1 \mathrm{H}, \mathrm{H} \beta-\mathrm{Thr}), 4.09-4.12$ (m, 2H, H6-Gal), 4.25 (t, $J=6.8 \mathrm{~Hz}, 1 \mathrm{H}, \mathrm{CH}-\mathrm{Fmoc}), 4.40-4.46$ (m, 4H, H $\alpha-\mathrm{Thr}$, $\mathrm{CH}_{2}$-Fmoc, H5-Gal), 4.57 (m, 1H, H2-Gal), 4.98 (d, $J=3.1 \mathrm{~Hz}$, 1H, H1-Gal), 5.13 (m, 1H, H3-Gal), 5.41 (m, 1H, H4-Gal), 5.61 (d, $J=9.1 \mathrm{~Hz}, 1 \mathrm{H}, \mathrm{NH}-\mathrm{Gal}), 5.93$ (d, $J=7.4 \mathrm{~Hz}, 1 \mathrm{H}, \mathrm{NH}-\mathrm{Thr}$ ), $7.32-7.45(\mathrm{~m}, 4 \mathrm{H}$, aryl- $\mathrm{H}), 7.62-7.66(\mathrm{~m}, 2 \mathrm{H}$, aryl- $\mathrm{H})$, 7.77-7.81 (m, 2H, aryl-H); ${ }^{13} \mathrm{C}$ NMR $\left(125.8 \mathrm{MHz}, \mathrm{CDCl}_{3}\right) \delta$ $14.2(\mathrm{C} \gamma-\mathrm{Thr}), 20.7\left(\mathrm{CH}_{3} \mathrm{CO}\right), 20.8\left(2 \times \mathrm{CH}_{3} \mathrm{CO}\right), 23.3$
$\left(\mathrm{CH}_{3} \mathrm{CO}\right), 28.1\left(\mathrm{CH}_{3}-t-\mathrm{Bu}\right), 47.1$ (CH-Fmoc), 48.0 (C2-Gal), 58.8 (C $\alpha$-Thr), 62.0 (C6-Gal), 67.1 ( $\mathrm{CH}_{2}$-Fmoc), 67.4 (C4-Gal, C5-Gal), 68.3 (C3-Gal), 76.1 (C $\beta$-Thr), 83.1 (C-t-Bu), 96.6 (C1-Gal), $120.0(2 \times), 125.1(2 \times), 127.1(2 \times), 127.7(2 \times), 141.3$ $(2 \times), 143.8$ (2× aryl), 155.9 (CO-Fmoc), 168.3, 169.9, 170.5, 170.0, 170.2 (CO); MS (ESI) $m / z:[\mathrm{M}+\mathrm{Na}]^{+} 749.1$.

$\mathrm{N}$-[(9H-Fluoren-9-yl)methoxycarbonyl]-3-O-(2-acetamido2-deoxy-3,4,6-tri- $O$-acetyl- $\alpha$-D-galactopyranosyl)-D-threonine tert-butyl ester (3B): Yield from 2B (5.99 g, $8.4 \mathrm{mmol})$ using GP2: $2.57 \mathrm{~g}(3.5 \mathrm{~mol}, 42 \%) ;[\alpha]_{\mathrm{D}}^{20}+58.2\left(c 0.5, \mathrm{CHCl}_{3}\right)$; ${ }^{1} \mathrm{H}$ NMR $\left(500 \mathrm{MHz}, \mathrm{CDCl}_{3}\right) \delta 1.18(\mathrm{~d}, J=7.2 \mathrm{~Hz}, 3 \mathrm{H}$, $\mathrm{H} \gamma$-Thr), 1.48 (s, 9H, $\mathrm{CH}_{3}$-t-Bu), 1.95 (s, 3H, $\mathrm{CH}_{3} \mathrm{CO}$ ), 1.99 (s, $3 \mathrm{H}, \mathrm{CH}_{3} \mathrm{CO}$ ), 2.01 (s, 3H, $\left.\mathrm{CH}_{3} \mathrm{CO}\right), 2.16$ (s, 3H, $\left.\mathrm{CH}_{3} \mathrm{CO}\right), 4.03$ (m, $J=9.8,6.6 \mathrm{~Hz}, 1 \mathrm{H}, \mathrm{H} 5-\mathrm{Gal}), 4.09-4.15$ (m, 2H, H6-Gal), $4.18-4.26$ (m, 2H, CH-Fmoc, H $\beta$-Thr), 4.33 (dd, $J=9.3,3.5$ $\mathrm{Hz}, 1 \mathrm{H}, \mathrm{H} \alpha-\mathrm{Thr}$ ), 4.48-4.60 (m, 3H, $\mathrm{CH}_{2}$-Fmoc, H2-Gal), 5.01 (d, $J=3.6 \mathrm{~Hz}, 1 \mathrm{H}, \mathrm{H} 1-\mathrm{Gal}), 5.06(\mathrm{dd}, J=11.4,3.2 \mathrm{~Hz}, 1 \mathrm{H}$, H3-Gal), 5.31 (m, 1H, H4-Gal), 5.57 (d, $J=9.2 \mathrm{~Hz}, 1 \mathrm{H}$, NH-Thr), 5.90 (d, $J=7.4 \mathrm{~Hz}, 1 \mathrm{H}, \mathrm{NH}-\mathrm{Gal}), 7.29-7.44$ (m, 4H, aryl-H), 7.58-7.65 (m, 2H, aryl-H), 7.75-7.79 (m, 2H, aryl-H); ${ }^{13} \mathrm{C}$ NMR $\left(125.8 \mathrm{MHz}, \mathrm{CDCl}_{3}\right) \delta 15.5(\mathrm{C} \gamma-\mathrm{Thr}), 20.7$ $\left(\mathrm{CH}_{3} \mathrm{CO}\right), 20.9\left(2 \times \mathrm{CH}_{3} \mathrm{CO}\right), 23.3\left(\mathrm{CH}_{3} \mathrm{CO}\right), 28.1\left(\mathrm{CH}_{3}-t-\mathrm{Bu}\right)$, 47.4 (CH-Fmoc), 47.8 (C2-Gal), 59.2 (C $\alpha$-Thr), 62.0 (C5-Gal), 66.9 (C6-Gal), 67.3 ( $\mathrm{CH}_{2}$-Fmoc), 67.4 (C4-Gal), 68.3 (C3-Gal), 72.5 (C $\beta$-Thr), 83.3 (C-t-Bu), 94.5 (C1-Gal), 120.2 (2×), 125.0, 125.1, $127.3(2 \times), 127.9(2 \times), 141.5(2 \times), 143.9,144.0$ (aryl), 156.6 (CO-Fmoc), 169.5, 170.3, 170.5, 171.1, 171.3 (CO); MS (ESI) $m / z:[\mathrm{M}+\mathrm{Na}]^{+} 749.3$.

\section{General synthetic procedure for the tert-butyl deprotection step (GP3)}

Fmoc-L-allo-Thr(GalNAc)-Ot-Bu (3A) or Fmoc-L-allo$\mathrm{Thr}$ (GalNAc)-Ot-Bu (3B) was dissolved in a mixture of TFA and water (95:5) and stirred for $90 \mathrm{~min}$. The volatiles were evaporated and the remaining residue was suspended in a mixture of acetonitrile and water and lyophilized three times in this solvent mixture. The crude product $\mathbf{4}$ was used without further purification.

$\mathrm{N}$-[(9H-Fluoren-9-yl)methoxycarbonyl]-3-O-(2-acetamido2-deoxy-3,4,6-tri-O-acetyl- $\alpha$-D-galactopyranosyl)-L-allothreonine (4A): Yield from 3A (2.40 g, $3.3 \mathrm{mmol})$ using GP3: $2.13 \mathrm{~g}(3.2 \mathrm{mmol}, 96 \%) ;[\alpha]_{\mathrm{D}}{ }^{20}+70.4\left(c 0.6, \mathrm{CHCl}_{3}\right) ;{ }^{1} \mathrm{H} \mathrm{NMR}$ (500 MHz, DMSO-d $)_{6} \delta 1.10$ (d, $\left.J=6.2 \mathrm{~Hz}, 3 \mathrm{H}, \mathrm{H} \gamma-\mathrm{Thr}\right), 1.82$ (s, 3H, $\mathrm{CH}_{3} \mathrm{CO}$ ), 1.89 (s, 3H, $\left.\mathrm{CH}_{3} \mathrm{CO}\right), 1.91$ (s, 3H, $\mathrm{CH}_{3} \mathrm{CO}$ ), 2.08 (s, 3H, $\mathrm{CH}_{3} \mathrm{CO}$ ), 3.89-3.92 (m, 2H, H6-Gal), 4.01-4.09 (m, 3H, H $\beta$-Thr, $\mathrm{CH}_{2}$-Fmoc), 4.18 (m, 1H, H2-Gal), 4.22-4.30 (m, 3H, H $\alpha$-Thr, H5-Gal, CH-Fmoc), 4.95 (dd, $J=11.9,3.1 \mathrm{~Hz}$, 1H, H3-Gal), 5.03 (d, $J=3.5 \mathrm{~Hz}, 1 \mathrm{H}, \mathrm{H} 1-\mathrm{Gal}), 5.27$ (m, 1H, H4-Gal), 7.31-7.44 (m, 4H, aryl-H), 7.72-7.76 (m, 2H, aryl-H), 
7.77 (d, $J=8.9 \mathrm{~Hz}, 1 \mathrm{H}, \mathrm{NH}-\mathrm{Thr}), 7.88-7.91$ (m, 2H, aryl-H), 7.96 (d, $J=7.8 \mathrm{~Hz}, 1 \mathrm{H}, \mathrm{NH}-\mathrm{Gal}), 12.91$ (s, br, $1 \mathrm{H}, \mathrm{COOH})$; ${ }^{13} \mathrm{C}$ NMR (125.8 MHz, DMSO-d $\left.d_{6}\right) \delta 15.5$ (C $\gamma$-Thr), 20.3 $\left(\mathrm{CH}_{3} \mathrm{CO}\right), 20.4\left(\mathrm{CH}_{3} \mathrm{CO}\right), 20.5\left(\mathrm{CH}_{3} \mathrm{CO}\right), 22.3\left(\mathrm{CH}_{3} \mathrm{CO}\right), 46.6$ (C2-Gal), 47.2 (CH-Fmoc), 58.6 ( $\mathrm{CH}_{2}$-Fmoc), 61.2 (C6-Gal), 65.9 (C $\alpha$-Thr), 66.4 (C5-Gal), 66.9 (C4-Gal), 67.3 (C3-Gal), 73.6 (C $\beta-T h r), 95.7$ (C1-Gal), $120.1(2 \times), 125.3(2 \times), 127.0$ $(2 \times), 127.6(2 \times), 140.7(2 \times), 143.7(2 \times$ aryl $), 156.2(\mathrm{CO}-F m o c)$, $169.7(3 \times), 169.9,171.7(\mathrm{CO})$; MS (ESI) $\mathrm{m} / z:[\mathrm{M}+\mathrm{Na}]^{+} 693.1$

$\mathrm{N}$-[(9H-Fluoren-9-yl)methoxycarbonyl]-3-O-(2-acetamido2-deoxy-3,4,6-tri- $O$-acetyl- $\alpha$-D-galactopyranosyl)-D-threonine (4B): Yield from 3B (2.57 g, $3.5 \mathrm{mmol})$ using GP3: $2.14 \mathrm{~g}$ (3.2 mmol, 90\%). $[\alpha]_{\mathrm{D}}{ }^{20}+59.7\left(c 0.5, \mathrm{CHCl}_{3}\right) ;{ }^{1} \mathrm{H}$ NMR (500 MHz, DMSO-d $\left.)_{6}\right) \delta 1.02$ (d, $J=6.2 \mathrm{~Hz}, 3 \mathrm{H}, \mathrm{H} \gamma$-Thr), 1.85 (s, $3 \mathrm{H}, \mathrm{CH}_{3} \mathrm{CO}$ ), 1.92 (s, 3H, $\mathrm{CH}_{3} \mathrm{CO}$ ), 1.97 (s, 3H, $\mathrm{CH}_{3} \mathrm{CO}$ ), 2.09 (s, 3H, $\left.\mathrm{CH}_{3} \mathrm{CO}\right), 3.88$ (dd, $\left.J=9.9,5.1 \mathrm{~Hz}, 1 \mathrm{H}, \mathrm{H} 6 \mathrm{a}-\mathrm{Gal}\right)$, 4.07-4.13 (m, 2H, H5-Gal, H6b-Gal), 4.21-4.30 (m, 3H, $\mathrm{H} \beta$-Thr, $\mathrm{CH}_{2}$-Fmoc), 4.30-4.45 (m, 3H, H2-Gal, H $\alpha$-Thr, CH-Fmoc), 4.88 (d, $J=3.7 \mathrm{~Hz}, 1 \mathrm{H}, \mathrm{H1}-\mathrm{Gal}), 4.94$ (dd, $J=11.6$, $3.3 \mathrm{~Hz}, 1 \mathrm{H}, \mathrm{H} 3-\mathrm{Gal}), 5.25$ ( $\mathrm{m}, J=3.3 \mathrm{~Hz}, 1 \mathrm{H}, \mathrm{H} 4-\mathrm{Gal})$, $7.26-7.44(\mathrm{~m}, 4 \mathrm{H}$, aryl-H), $7.62(\mathrm{~d}, J=8.6 \mathrm{~Hz}, 1 \mathrm{H}, \mathrm{NH}-\mathrm{Gal})$, 7.70-7.77 (m, 2H, aryl-H), 7.87-7.91 (m, 2H, aryl-H), 8.01 (d, $J=9.3 \mathrm{~Hz}, 1 \mathrm{H}, \mathrm{NH}-\mathrm{Thr}), 13.03$ (s, br, $1 \mathrm{H}, \mathrm{COOH}) ;{ }^{13} \mathrm{C}$ NMR (125.8 MHz, DMSO- $\left.d_{6}\right) \delta 14.4(\mathrm{C} \gamma-\mathrm{Thr}), 20.4\left(\mathrm{CH}_{3} \mathrm{CO}\right), 20.5$ (2× $\left.\mathrm{CH}_{3} \mathrm{CO}\right), 22.5\left(\mathrm{CH}_{3} \mathrm{CO}\right), 45.4$ (C2-Gal), 47.3 (CH-Fmoc), 58.3 (C $\mathrm{C}-\mathrm{Thr}), 61.1$ (C6-Gal), 65.7 ( $\mathrm{CH}_{2}$-Fmoc), 66.2 (C5-Gal), 66.8 (C4-Gal), 67.9 (C3-Gal), 70.6 (C $\beta-T h r), 92.9$ (C1-Gal), $120.1(2 \times), 125.1,125.3,127.0(2 \times), 127.7(2 \times), 140.8(2 \times)$, 143.7, 144.0 (aryl), 156.8 (CO-Fmoc), 169.4, 169.8, $170.0(2 \times)$, 172.0 (CO); MS (ESI) $m / z:[\mathrm{M}+\mathrm{Na}]^{+}$693.2, $[\mathrm{M}+\mathrm{K}]^{+}$715.1.

\section{Synthesis of AFGP analogues and their agly- cons}

Synthesis of the peptides was conducted in a microwave reactor in an automatic fashion for the aglycons (6 and 8) and semiautomatically for the AFGP analogues (5 and 7) on a $0.10 \mathrm{mmol}$ scale. The 2-chlorotrityl resin was loaded manually either with Fmoc-L-Ala-OH (resin loading $0.59 \mathrm{mmol} \mathrm{g}^{-1}$ ) for the allo-LThr containing peptides or with Fmoc-D-Ala-OH (resin loading $0.38 \mathrm{mmol} \mathrm{g}^{-1}$ ) for the retro-inverso peptides. All cycles for the synthesis of the glycosylated peptides and aglycons follow a published procedure $[16,23]$. The automated synthesis of the aglycons was performed under microwave irradiation at a maximum of $78{ }^{\circ} \mathrm{C}$ at $35 \mathrm{~W}$, whereas for the glycopeptides lower temperatures limited to $40{ }^{\circ} \mathrm{C}$ at $20 \mathrm{~W}$ were employed. The resin was treated twice with piperidine in DMF $(20 \%$, v/v, $7 \mathrm{~mL}$ ) for $7 \mathrm{~min}$ to cleave Fmoc. Coupling of Fmoc-L/D-Ala$\mathrm{OH}$ and Fmoc-L/D-Thr( $t$-Bu)-OH, ( $0.50 \mathrm{mmol}, 5.0$ equiv) was conducted in 10 min by using a solution of the particular amino acid in DMF (2.5 mL), TBTU (0.50 mmol, 5.0 equiv) in DMF
$(1 \mathrm{~mL})$ and DIPEA (1.0 mmol, 10 equiv) in NMP $(0.5 \mathrm{~mL})$. Fmoc-allo-L/D-Thr(Ac $\mathrm{Ac}_{3}$ GalNAc)-OH 4A/B (0.25 mmol, 2.5 equiv) were preactivated with $\mathrm{HATU}(0.28 \mathrm{mmol} 2.8$ equiv) in DMF ( $1 \mathrm{~mL})$ and DIPEA (0.28 mmol, 2.75 equiv) for $2 \mathrm{~min}$ and added manually to the reaction vessel of the peptide synthesizer. Subsequently, HOAt ( $0.25 \mathrm{mmol}, 2.25$ equiv) dissolved in DMF $(1 \mathrm{~mL})$ and DIPEA ( $0.28 \mathrm{mmol}, 2.75$ equiv) were transferred manually. Unreacted amino groups were capped by an acetylation reaction after coupling of the glycosylated building block using acetic anhydride $(0.5 \mathrm{~mol})$ in the presence of DIPEA $(0.13 \mathrm{~mol})$ in DMF $(10 \mathrm{~mL})$. The acetate groups protecting the carbohydrate hydroxy groups in the glycopeptides were removed manually using $5 \%$ hydrazine in DMF $(\mathrm{v} / \mathrm{v}, 5 \mathrm{~mL})$ for $6-15 \mathrm{~h}$. The peptides were cleaved from the resin by treatment with TFA in methylene chloride $(2 \%, \mathrm{v} / \mathrm{v}, 10$ $\times 5 \mathrm{~mL} \times 5 \mathrm{~min}$ ) and were collected in a flask containing isopropanol. The peptides were precipitated with cold diethyl ether and the crude products were separated from the remaining solvent by centrifugation. Subsequently, the aglycons were treated with TFA/ $\mathrm{H}_{2} \mathrm{O} / \mathrm{TIS}(95: 2.5: 2.5)$ for $30 \mathrm{~min}$ after cleavage from the resin. Finally, the peptides were purified by preparative RP-HPLC.

H-[L-Ala-L-Ala-allo-L-Thr(GalNAc) ]4-L-Ala-L-Ala-OH (5, $6 \mathrm{mg}, 3 \%$ ): calcd for $\mathrm{C}_{78} \mathrm{H}_{132} \mathrm{~N}_{18} \mathrm{O}_{39}, 1945.98$ (av.); found, 1944.889917 (monoisotopic); MS (ESI) $m / z:[\mathrm{M}+\mathrm{Na}]^{+} 1969.2$; HRMS (ESI): $[\mathrm{M}+\mathrm{H}+\mathrm{Na}]^{2+} 984.44622 ;[\mathrm{M}+2 \mathrm{Na}]^{2+}$ 995.43429 .

H-[L-Ala-L-Ala-allo-L-Thr] 4 -L-Ala-L-Ala-OH (6, 2 mg, 2\%): calcd for $\mathrm{C}_{46} \mathrm{H}_{80} \mathrm{~N}_{14} \mathrm{O}_{19}, 1133.21$ (av.); found, 1132.572420 (monoisotopic); MS (MALDI-TOF) $\mathrm{m} / \mathrm{z}$ : $[\mathrm{M}+\mathrm{Na}]^{+}$1155.7; HRMS (ESI): $[\mathrm{M}+\mathrm{H}]^{+} 1133.58309$.

H-[D-Ala-D-Ala-D-Thr(GalNAc) $]_{4}$-D-Ala-D-Ala-OH (7, $10 \mathrm{mg}, 5 \%$ ): calcd for $\mathrm{C}_{78} \mathrm{H}_{132} \mathrm{~N}_{18} \mathrm{O}_{39}, 1945.98$ (av.); found, 1944.889917 (monoisotopic); MS (ESI) $m / z:[\mathrm{M}+\mathrm{Na}]^{+}$1968.0; $[\mathrm{M}+\mathrm{K}]^{+}$1983.9; HRMS (ESI): $[\mathrm{M}+2 \mathrm{Na}]^{2+} 995.43709$.

H-[D-Ala-D-Ala-D-Thr] 4 -D-Ala-D-Ala-OH (8, $2 \mathrm{mg}, 2 \%)$ : calcd for $\mathrm{C}_{46} \mathrm{H}_{80} \mathrm{~N}_{14} \mathrm{O}_{19}, 1133.21$ (av.); found, 1132.572420 (monoisotopic); MS (ESI) $m / z:[\mathrm{M}+\mathrm{Na}]^{+} 1155.4$; HRMS $(\mathrm{ESI}):[\mathrm{M}+2 \mathrm{Na}]^{2+} 578.28376$.

\section{Microphysical ice recrystallization analysis}

The antifreeze activity was determined according to a method described previously. The inhibitory effect of antifreeze agents on ice recrystallization is quantified: The peptides (TFA salts) were dissolved in $45 \mathrm{wt} \%$ sucrose solutions in varying concentrations and $2 \mu \mathrm{L}$ of each of these solutions were placed between glass cover slides (film thickness $\sim 10-20 \mu \mathrm{m}$ ). The 
samples were positioned on a temperature-controlled silver block inside a cold stage (Linkam MDBCS 196) mounted onto an optical microscope (Olympus BX 51) in bright field transmission mode. The samples were cooled down to $-50{ }^{\circ} \mathrm{C}$ at a rate of $20{ }^{\circ} \mathrm{C} \mathrm{min}-1$, reheated to $-8{ }^{\circ} \mathrm{C}$ at a rate of $10{ }^{\circ} \mathrm{C} \mathrm{min}^{-1}$, and annealed at this temperature for $2 \mathrm{~h}$. The recrystallization of the resulting polycrystalline ice was recorded by taking images with a digital video camera in $12 \mathrm{~s}$ time intervals while the images were analyzed simultaneously by using a LabVIEW virtual instrument. The ice recrystallization rate was calculated to obtain the inhibitor related concentration $c_{\mathrm{i}}$ at which the recrystallization-limiting process turns over from water diffusion to liquid-to-ice transfer due to the presence of ice-binding antifreeze agent [37,38].

\section{Acknowledgements}

The authors gratefully acknowledge support from the Deutsche Forschungsgemeinschaft (SFB 613, project A8). L. N. was funded by a $\mathrm{PhD}$ fellowship from Bielefeld University.

\section{References}

1. Brown, R. A.; Yeh, Y.; Burcham, T. S.; Feeney, R. E. Biopolymers 1985, 24, 1265-1270. doi:10.1002/bip.360240713

2. Harding, M. M.; Anderberg, P. I.; Haymet, A. D. Eur. J. Biochem. 2003, 270, 1381-1392. doi:10.1046/j.1432-1033.2003.03488.x

3. Knight, C. A.; DeVries, A. L.; Oolman, L. D. Nature 1984, 308, 295-296. doi:10.1038/308295a0

4. Bouvet, V.; Ben, R. N. Cell Biochem. Biophys. 2003, 39, 133-144. doi:10.1385/CBB:39:2:133

5. Peltier, R.; Brimble, M. A.; Wojnar, J. M.; Williams, D. E.; Evans, C. W.; DeVries, A. L. Chem. Sci. 2010, 1, 538-551. doi:10.1039/c0sc00194e

6. Davies, P. L.; Sykes, B. D. Curr. Opin. Struct. Biol. 1997, 7, 828-834. doi:10.1016/S0959-440X(97)80154-6

7. Garner, J.; Harding, M. M. ChemBioChem 2010, 11, 2489-2498. doi:10.1002/cbic.201000509

8. Feeney, R. E. Am. Sci. 1974, 62, 712-719.

9. Lin, Y.; Duman, J. G.; DeVries, A. L. Biochem. Biophys. Res. Commun. 1972, 46, 87-92. doi:10.1016/0006-291X(72)90633-X

10. Morris, H. R.; Thompso, M. R.; Osuga, D. T.; Ahmed, A. I.; Chan, S. M.; Vandenheede, J. R.; Feeney, R. E. J. Biol. Chem. 1978 253, 5155-5162.

11. Burcham, T. S.; Osuga, D. T.; Rao, B. N.; Bush, C. A.; Feeney, R. E. J. Biol. Chem. 1986, 261, 6384-6389.

12. Tachibana, Y.; Fletcher, G. L.; Fujitani, N.; Tsuda, S.; Monde, K.; Nishimura, S.-I. Angew. Chem. 2004, 116, 874-880. doi:10.1002/ange.200353110

13. Bush, C. A.; Ralapati, S.; Matson, G. M.; Yamasaki, R. B.; Osuga, D. T.; Yeh, Y.; Feeney, R. E. Arch. Biochem. Biophys. 1984, 232, 624-631. doi:10.1016/0003-9861(84)90582-4

14. Lane, A. N.; Hays, L. M.; Crowe, L. M.; Crowe, J. H.; Feeney, R. E. Protein Sci. 1998, 7, 1555-1563. doi:10.1002/pro.5560070709

15. Lane, A. N.; Hays, L. M.; Tsvetkova, N.; Feeney, R. E.; Crowe, L. M.; Crowe, J. H. Biophys. J. 2000, 78, 3195-3207. doi:10.1016/S0006-3495(00)76856-1
16. Heggemann, C.; Budke, C.; Schomburg, B.; Majer, Z.; Wißbrock, M.; Koop, T.; Sewald, N. Amino Acids 2010, 38, 213-222. doi:10.1007/s00726-008-0229-0

17. Norgren, A. S.; Budke, C.; Majer, Z.; Heggemann, C.; Koop, T.; Sewald, N. Synthesis 2009, 488-494. doi:10.1055/s-0028-1083302

18. Liu, S.; Ben, R. N. Org. Lett. 2005, 7, 2385-2388. doi:10.1021/ol050677x

19. Capicciotti, C. J.; Trant, J. F.; Leclére, M.; Ben, R. N. Bioconjugate Chem. 2011, 22, 605-616. doi:10.1021/bc100394k

20. Chorev, M.; Goodman, M. Acc. Chem. Res. 1993, 26, 266-273. doi:10.1021/ar00029a007

21. Paulsen, H.; Hölck, J.-P. Carbohydr. Res. 1982, 109, 89-107. doi:10.1016/0008-6215(82)84033-0

22. Plattner, C.; Höfener, M.; Sewald, N. Org. Lett. 2011, 13, 545-547. doi:10.1021/ol102750h

23. Nagel, L.; Plattner, C.; Budke, C.; Majer, Z.; DeVries, A. L.; Berkemeier, T.; Koop, T.; Sewald, N. Amino Acids 2011, 41, 719-732. doi:10.1007/s00726-011-0937-8

24. Rosen, T.; Lico, I. M.; Chu, D. T. W. J. Org. Chem. 1988, 53, 1580-1582. doi:10.1021/jo00242a051

25. Liebe, B.; Kunz, H. Helv. Chim. Acta 1997, 80, 1473-1482. doi:10.1002/hlca.19970800511

26. Chen, K.; Liu, Z.; Kallenbach, N. R. Proc. Natl. Acad. Sci. U. S. A. 2004, 101, 15352-15357. doi:10.1073/pnas.0406657101

27. Liu, Z.; Chen, K.; Ng, A.; Shi, Z.; Woody, R. W.; Kallenbach, N. R. J. Am. Chem. Soc. 2004, 126, 15141-15150. doi:10.1021/ja047594g

28. Hanessian, S.; Lavallee, P. Can. J. Chem. 1975, 53, 2975-2977. doi:10.1139/v75-419

29. Owens, N. W.; Stetefeld, J.; Lattová, E.; Schweizer, F. J. Am. Chem. Soc. 2010, 132, 5036-5042. doi:10.1021/ja905724d

30. Tatham, A. S.; Drake, A. F.; Shewry, P. R. Biochem. J. 1989, 259 , 471-476.

31. Bhatnagar, R. S.; Gough, C. A. Circular Dichroism of collagen and related polypeptides. In Circular Dichroism and the conformational analysis of biomolecules; Fasman, G. D., Ed.; Plenum Press: New York, 1996; pp 183-199.

32. Bhatnagar, R. S.; Qian, J. J.; Gough, C. A. J. Biomol. Struct. Dyn. 1997, 14, 547-560. doi:10.1080/07391102.1997.10508155

33. Greenfield, N.; Fasman, G. D. Biochemistry 1969, 8, 4108-4116. doi:10.1021/bi00838a031

34. Knight, C. A.; Hallett, J.; DeVries, A. L. Cryobiology 1988, 25, 55-60. doi:10.1016/0011-2240(88)90020-X

35. Knight, C. A.; Wen, D.; Laursen, R. A. Cryobiology 1995, 32, 23-34. doi:10.1006/cryo.1995.1002

36. Budke, C.; Koop, T. ChemPhysChem 2006, 7, 2601-2606. doi:10.1002/cphc.200600533

37. Budke, C.; Heggemann, C.; Koch, M.; Sewald, N.; Koop, T. J. Phys. Chem. B 2009, 113, 2865-2873. doi:10.1021/jp805726e

38. Nagel, L.; Budke, C.; Erdmann, R. S.; Dreyer, A.; Wennemers, H.; Koop, T.; Sewald, N. Chem.-Eur. J. 2012, in press. doi:10.1002/chem.201202119

39. Corzana, F.; Busto, J. H.; Jiménez-Osés, G.; Asensio, J. L.; Jiménez-Barbero, J.; Peregrina, J. M.; Avenoza, A. J. Am. Chem. Soc. 2006, 128, 14640-14648. doi:10.1021/ja064539u

40. Tam, R. Y.; Rowley, C. N.; Petrov, I.; Zhang, T.; Afagh, N. A.; Woo, T. K.; Ben, R. N. J. Am. Chem. Soc. 2009, 131, 15745-15753. doi:10.1021/ja904169a

41. Ebbinghaus, S.; Meister, K.; Born, B.; DeVries, A. L.; Gruebele, M.; Havenith, M. J. Am. Chem. Soc. 2010, 132, 12210-12211. doi:10.1021/ja1051632 
42. Czechura, P.; Tam, R. Y.; Dimitrijevic, E.; Murphy, A. V.; Ben, R. N. J. Am. Chem. Soc. 2008, 130, 2928-2929. doi:10.1021/ja7103262

\section{License and Terms}

This is an Open Access article under the terms of the Creative Commons Attribution License

(http://creativecommons.org/licenses/by/2.0), which permits unrestricted use, distribution, and reproduction in any medium, provided the original work is properly cited.

The license is subject to the Beilstein Journal of Organic Chemistry terms and conditions:

(http://www.beilstein-journals.org/bjoc)

The definitive version of this article is the electronic one which can be found at:

doi:10.3762/bjoc. 8.190 